Research Paper

International Journal of Medical Sciences

ISSN 1449-1907 www.medsci.org 2008 5(6):354-360

(C) Ivyspring International Publisher. All rights reserved

\title{
An innovative method to evaluate the suture compliance in sealing the surgical wound lips
}

\author{
Farid Saleh ${ }^{1}$, Beniamino Palmieri2, Danielle Lodi², and Khalid Al-Sebeih ${ }^{3}$
}

1. Department of Anatomy, Faculty of Medicine, Health Science Centre, Kuwait University, Kuwait.

2. Department of General Surgery and Surgical Specialty, University of Modena and Reggio Emilia, Surgical Clinics, Via del Pozzo, 71, 41100 Modena, Italy.

3. Department of Surgery, Head and Neck Surgery, Faculty of Medicine, Health Science Centre, Kuwait University, Kuwait.

$\triangle$ Correspondence to: Dr. Farid Saleh, Department of Anatomy, Faculty of Medicine, Health Science Centre, Kuwait University, P.O. Box 24923, Safat 13110, Kuwait. Fax:+965/ 5319478, E-mail: fred@hsc.edu.kw

Received: 2008.10.23; Accepted: 2008.11.07; Published: 2008.11.11

Background and aim: The increasing number of surgical procedures performed with local anesthesia, followed by immediate patient discharge from the hospital, emphasizes the need for a tight waterproof suture that is capable of maintaining its tensile strength in the postoperative phase when the wound tumescence, edema due to the anesthetic drug, and surgical trauma disappear. Moreover, the issue of having an accurate surgical wound closure is very relevant in vivo in order to prevent hemorrhage and exogenous microbial infections. This study aimed at designing a new a lab technique that could be used for evaluating the best surgical material. Using such a technique, we compared the wound-lip-sealing properties of three commonly-used suture threads, namely polyurethane, polypropylene, and polyamide.

Materials and methods: The mechanical properties of same-size suture threads made from polyurethane, polypropylene, and polyamide, were compared in order to define the one that possess the best elastic properties by being able to counteract the tension-relaxation process in the first 12 hours following surgery. The tension holding capacity of the suture materials was measured in both in vivo and in vitro experiments. The surface area of the scar associated with the three different suture threads was measured and compared, and the permeability of the three different suture threads was assessed at 0 minute, 2 minute, 4 minute, 6 minute, and 8 minute- interval.

Results: Results showed that polyurethane suture threads had significantly $(\mathrm{P}<0.05)$ better tensile strength, elongation endurance before breakage, and better elasticity coefficient as compared to polypropylene and polyamide suture threads. Moreover, polyurethane suture threads were significantly $(\mathrm{P}<0.05)$ more impermeable as compared to the other two suture thread types (polypropylene and polyamide). This impermeability was also associated with a tighter wound-lip-sealing ability, and with significantly $(\mathrm{P}<0.05)$ less scar formation.

Conclusion: Among the main concerns that surgeons, physicians, and patients often have is the development infection, oozing, and scar at the incision site following suturing. This always raises the question about which suture to use to avoid the above problems. This study provides evidence that the new technique developed in our lab could be used to compare the wound-lip sealing properties of different surgical suture threads. Using such a technique, the results show that polyurethane is significantly better than other commonly-used suture threads, like polypropylene and polyamide, in relation to wound sealing and scar formation.

Key words: suture threads, polyurethane, polypropylene, polyamide, wound-lip-sealing properties

\section{INTRODUCTION}

There are different types of suture threads that are being used for tissue closure in different types of surgeries and invasive procedures (Table 1) [1, 2]. The mechanical characteristics of suture lines depend on the intrinsic nature of the suture material used [3, 4,5]. Such characteristics include tensile strength, smoothness, memory, and elasticity.
The tensile strength of a suture often used for tissue closure is defined as the amount of weight required to break the suture, divided by the suture's cross-sectional area [2]. The cross section of the suture is conventionally measured by the size of the suture threads from 0 to $1 / 0,2 / 0,3 / 0$, etc., and the smaller the size of the suture the milder would often be the inflammatory process due to reduced foreign body reaction $[2,5]$. Accordingly, the surgeons always have 
the challenge of being able to select the thinnest suture, especially the one with non-absorbable material, pos-

sibly non-filamentous, easy to be tied, and easily and painlessly removed.

Table 1: A summary of the most commonly used sutures.

\begin{tabular}{|c|c|c|c|c|c|}
\hline Material & Configuration & Tensile strength & $\begin{array}{l}\text { Absorption } \\
\text { time }\end{array}$ & Knot & Use \\
\hline $\begin{array}{l}\text { VICRYL RAPID: glycol and lactide } \\
\text { copolimer coated by polyglactin } 370 \\
\text { and } \mathrm{Ca}^{++} \text {stearate }\end{array}$ & braided & $45 \%$ at 7 days & 50 days & good & $\begin{array}{l}\text { Subcutaneous and cutaneous clo- } \\
\text { sure, pediatric, and obstet- } \\
\text { rics-gynecology }\end{array}$ \\
\hline $\begin{array}{l}\text { VICRYL COATED: glycol and lactide } \\
\text { copolymer coated by polyglactin } 370, \\
910 \text { and } \mathrm{Ca}^{++} \text {stearate }\end{array}$ & braided & $65 \%$ at 14 days & 50-70 days & good & $\begin{array}{l}\text { not for tissue continuously } \\
\text { stressed }\end{array}$ \\
\hline $\begin{array}{l}\text { MONOCRYL: glycolide and epsilopn } \\
\text { caprolacton copolymer }\end{array}$ & monofilament & $50 \%$ at 14 days & 105 days & good & $\begin{array}{l}\text { Obstetrics- gynecology, urology, } \\
\text { plastic, abdominal, and vascular }\end{array}$ \\
\hline POLYDIOXANONE: ester polymer & monofilament & $70 \%$ at 14 days & 200 days & poor & $\begin{array}{l}\text { Abdominal, thoracic, subcutane- } \\
\text { ous, intestinal, vascular, pediatric, } \\
\text { plastic, oncology, orthopedic }\end{array}$ \\
\hline $\begin{array}{l}\text { PANACRYL: glycolide and lactide } \\
\text { copolymer coated by caprolactone and } \\
\text { glycolide }\end{array}$ & braided & $80 \%$ at 3 months & 18-24 months & good & $\begin{array}{l}\text { Tendons, ligaments, and articular } \\
\text { capsules }\end{array}$ \\
\hline SURGICAL GUT (plain) & twisted & poor at $7-10$ days & 6-8 weeks & poor & $\begin{array}{l}\text { Subcutaneous closure, and closure } \\
\text { of punch biopsies }\end{array}$ \\
\hline SURGICAL GUT (fast-absorbing) & twisted & $50 \%$ at $3-5$ days & 2-4 weeks & poor & Subcutaneous closure \\
\hline SURGICAL GUT (chromic) & twisted & $\begin{array}{l}\text { poor at } 21-28 \\
\text { days }\end{array}$ & $8-10$ weeks & poor & $\begin{array}{l}\text { Subcutaneous closure, and vessel } \\
\text { ligature }\end{array}$ \\
\hline COTTON & twisted & good & / & good & None \\
\hline SURGERY SILK & braided/twisted & none in 1 years & / & excellent & $\begin{array}{l}\text { General, ophthalmic, and plastic } \\
\text { surgeries }\end{array}$ \\
\hline $\begin{array}{l}\text { SURGERY STEEL: metallic alloy of } \\
\text { steel-nickel-chrome }\end{array}$ & mono/multifilament & indefinitely & / & poor & $\begin{array}{l}\text { Abdominal and cutaneous sur- } \\
\text { geries, tendon repair, orthopedics, } \\
\text { and neurosurgery }\end{array}$ \\
\hline NYLON: polyamide polymer & monofilament & $20 \%$ per years & / & good & $\begin{array}{l}\text { Skin closure, blood vessel ligature, } \\
\text { and plastic and ophthalmic sur- } \\
\text { geries }\end{array}$ \\
\hline NUROLON: polyamide polymer & monofilament & indefinitely & / & good & $\begin{array}{l}\text { Skin closure, general, cardiovas- } \\
\text { cular, and plastic surgeries }\end{array}$ \\
\hline PROLENE: propylene polymer & monofilament & indefinitely & / & good & $\begin{array}{l}\text { Skin closure, subcuticular, general, } \\
\text { plastic, cardiovascular, and oph- } \\
\text { thalmic surgeries }\end{array}$ \\
\hline $\begin{array}{l}\text { MESILENE: tereftalic acid and poly- } \\
\text { ethylene polymer }\end{array}$ & braided & indefinitely & / & $\begin{array}{l}\text { very } \\
\text { good }\end{array}$ & $\begin{array}{l}\text { Skin closure, general, cardiovas- } \\
\text { cular, and plastic surgeries }\end{array}$ \\
\hline $\begin{array}{l}\text { ETHIBOND EXCEL: tereftalic acid } \\
\text { and polyethylene polymer coated by } \\
\text { polybutilate }\end{array}$ & braided & indefinitely & / & $\begin{array}{l}\text { very } \\
\text { good }\end{array}$ & $\begin{array}{l}\text { Skin closure, general, cardiovas- } \\
\text { cular, and plastic surgeries }\end{array}$ \\
\hline $\begin{array}{l}\text { PROVOVA: polyvilden- } \\
\text { fluoro-exafluoropropylene polymer }\end{array}$ & monofilament & indefinitely & / & $\begin{array}{l}\text { very } \\
\text { good }\end{array}$ & $\begin{array}{l}\text { Skin closure, plastic, ophthalmic, } \\
\text { general, cardiovascular, and plas- } \\
\text { tic surgeries }\end{array}$ \\
\hline NOVARFIL: polybutester polymer & monofilament & indefinitely & / & good & Skin closure \\
\hline $\begin{array}{l}\text { POLYURETHANE: polyurethane } \\
\text { polymer }\end{array}$ & monofilament & indefinitely & / & $\begin{array}{l}\text { very } \\
\text { good }\end{array}$ & $\begin{array}{l}\text { Skin closure, general, cardiovas- } \\
\text { cular, and plastic surgeries }\end{array}$ \\
\hline
\end{tabular}

The smoothness of the suture results from the molecular characteristics of its thread, or from a specific treatment of its surface that helps in reducing tissue trauma when the suture is passing across the wound margins $[5,6]$. It is related to the knot strength which is expressed by the friction coefficient, and to also the resistance force produced by the cross-sectional deformity of the threads [2]. Using the "pull-out friction test", it is possible to define silk as the gold standard suture material in terms of knot security because of its high static withdrawal resistance under low loads and relatively low dynamic with- drawal resistance under high loads [6]. In high tension wounds, the usage of greater tensile strength and knot security is advisable. The choice is to use multifilament not absorbable suture threads like silk, but the surgeons sometimes prefer the usage of absorbable long standing suture threads that are buried under the skin, thus holding the margins tightly and reducing the tag of the tans-cutaneous epidermal suture threads $[7,8]$. A suture pull-out tester includes a load cell assembly, a drive track, a jig and a drive assembly. The load cell assembly has a force measuring device and an attachment member for retaining one end of a filament. 
The jig includes a receptacle dimensioned to receive a suture package. The jig is driven along the drive track by the drive assembly such that the attachment member draws the filament from the suture package. The force measuring device measures the forces required to withdraw the filament from the suture package.

Suture memory and elasticity are inter-related. The former is defined as its ability to return to its original shape after being manipulated. The latter is defined as its property to elongate when the tissue is swollen, as it usually happens with surgical trauma, and to return to the previous length after the tension force is withdrawn [8]. The elastic property of the suture can prevent skin strangulation or necrosis, which often result in permanent scars. The suture thread should be stiff enough to hold steadily the knot avoiding slacking, but, also should have some elasticity to counteract the tension to which the wound margin is often exposed [8].

Ideally, a suture should be inert, that is not chemically-reacting with the environment, biocompatible, that is lacking pyrogenic and antigenic properties, and possibly capable of counteracting bacterial colonization along the suture track [9]. Infection is often considered as the worst complication of a sutured wound, and bacteria usually multiply in the area where necrosis is present or where blood is being pooled into the wound bed [9]. Once again, the suture knot plays a pivotal role in this process, whereby necrosis of the skin (especially in trauma wounds, or in dystrophic elderly skin) can be induced if it is too tight. On the other hand, if the suture knot is too relaxed, the wound line will not be not sealed enough to prevent infiltration of microbes or other foreign bodies $[9,10]$.

Wound infections are usually exogenous in origin, but some predisposing factors, such as poor hygiene, contamination of the suture material, wound hematoma, or necrotic tissue (sometimes due to exceeding traction of the suture or poor vascular supply) favors exogenous or endogenous bacterial proliferation [10]. In this study, another relevant risk factor was introduced, namely unfitness (incomplete sealing off) of the wound-lip margin due to suture relaxation in the first 24 hour postoperative. This phenomenon is very relevant, especially when local anesthesia is performed in an outpatient-day-surgery procedure [11]. In the latter, the tissue surrounding the wound is swollen due to subcutaneous drug injection. This results from vasodilatation that is drug-induced. Such vasodilatation, in addition to the surgical trauma, often last between 8 and 24 hours post-op. This is followed by a gradual recovery of the tissue volume to the initial baseline [11]. Accordingly, the ideal suture thread should maintain a perfect wound closure, by having enough elastic properties to hold the knot while maintaining tensile strength either in the swollen or in the late decongestive phase of the surgically-injured tissue.

This study aimed at designing a new a lab technique that could be used for evaluating the best surgical material. Using such a technique, we compared the wound-lip-sealing properties of three commonly-used suture threads, namely polyurethane, polypropylene, and polyamide.

\section{MATERIALS and METHODS}

\section{Suture materials}

Identical size $(0.2 \mathrm{~mm}$ of thickness and $450 \mathrm{~mm}$ of length.) monofilament suture threads were chosen for the study. These included 25 polypropylene (ASSUPRO) suture threads, 25 polyurethane (ASSUPLUS) suture threads, and 25 polyamide (ASSUNYL) suture threads (FabbrAssut Europe, Magliano dei Marsi AQ, Italy).

\section{Tensile strength, elongation, and elasticity coefficient}

The tensile strength was defined as the maximum strength that the suture thread can sustain against force before it breaks. Elongation was defined as the maximum length that the suture thread can reach in association with the tensile strength. The elasticity coefficient was defined as the degree of elasticity of the suture thread while reacting to a traction force.

To evaluate the above parameters, every suture in each group ( 25 polypropylene, 25 polyurethane, and 25 polyamide) was tested with a dynamometer (Mecmesin, Corsico Milanese, Milano), and the mean within each group was then calculated. Briefly, both ends of a thread were fixed by a staple at the crooked (anchor) arms of the dynamometer. The distance between the crooks was $30 \pm 5 \mathrm{~mm}$ (the optimal distance preventing interference), and the velocity was $50 \mathrm{~mm} / \mathrm{sec}$. The test ends at the break point. The breakage strength was measured by the dynamometric cell (sensibility $0.01 \mathrm{~N}$ ), while the elongation was calculated by subtracting $30 \mathrm{~mm}$ from the distance achieved by the crooks at the break time [6-10].

\section{Permeability test on phantom}

A polyurethane device (mimicking the epidermis), and porous polyurethane open cells (mimicking the dermis and the subcutaneous tissue) were embedded by immersion in saline for 20 minutes [12]. One hour later, this "artificial skin" was cut by a 16 blade with three parallel incisions $50 \mathrm{~mm}$ long and $30-40 \mathrm{~mm}$ apart. The different suture threads were used to close the wound using the square knot technique. Every knot was pinched by applying a force of 
0.4-1 N (measured with a dynamometric cell) to standardize the tensile strength. This was followed by drying the "artificial skin" in an incubator at $37^{\circ} \mathrm{C}$ and $60^{\circ}$ humidity for eight hours. Thereafter, $0.2 \mathrm{ml}$ of bromoethylene blue was dropped over each sutured wound in a horizontal plane (one drop over one centimeter of the incision line released from a height of 0.5 $\mathrm{cm})$. This is to evaluate the permeability of each suture on the basis of the uptake of the stain by the wound bed. The diffusion of the stain was followed up every 2 minutes $(0,2,4,6$, and $8 \mathrm{~min})$, with digital photos (3 per suture) taken of the suture threads until the remaining stain (if any) dried. Such photos were then analyzed to measure the surface stain area using an image analysis system (IAS). We chose the above timing because we found by trial and error that there will be no stain left after 8 minutes, and that it takes 2 minutes for the stain to move from one phase to another, i.e. strong stain, then weaker stain. Moreover, there is currently no commercial stain which, if used under the normal wound conditions, would last for 8-24 hrs. The IAS consisted of an observer-interactive computerized image analysis (SAMBA microscopic image processor; Meylan, France), the hardware and software of which have been described by Brugal and colleagues [13]. This system is fitted with a standard axioplan microscope with an automated stage (Carl Zeiss; Oberkochen, Germany) allowing a precise location of a particular field through the XYZ axis plotting, a colour video camera (Sony Corporation; Tokyo, Japan), an image analysis processor (Matrox; Montreal, QC, Canada), and a personal computer (Pentium 2, 166-MHZ processor; Intel; Santa Clara, CA).

\section{Clinical study}

Linear skin suture threads were performed by the same plastic and reconstructive surgeon on healthy patients operated for laparocele $(n=10 ; 5$ males and 5 females aged between 40 and 45 years), hernia ( $n=10$; 5 males and 5 females aged between 40 and 45 years), lipomas ( $\mathrm{n}=10 ; 5$ males and 5 females aged between 40 and 45 years), and scar revision ( $n=10 ; 5$ males and 5 females aged between 40 and 45 years). The line was subdivided in three identical segments each sutured with a different thread (polyurethane, polypropylene, and polyamide) placed randomly (using a computer generated list of random numbers; Excel version 5.0) in the middle or the lateral part of the wound line. In order to hold correctly the knot without creating a difference in the tension on the suture, a hydrocolloid layer (Duoderm extrathin, Convatec) was applied on the wound margin before epidermal suture transfixion. The disruption and laceration of this layer was used as an indicator of excessive force in the knotting procedure. When the latter took place, the case was dropped out and replaced by another new one. This took place with three cases for laparocele and two for hernia. The suture threads and hydrocolloid were removed on the fifth postoperative day, and three digital photos of each suture line were analyzed to measure the width of the scar using the IAS described earlier.

\section{STATISTICAL ANALYSIS}

The unpaired two-tailed student $\mathrm{t}$ test was used to compare the means among the three suture thread groups (polyurethane, polypropylene, and polyamide) in relation to tensile strength, elongation, elasticity coefficient, stained surface area at $0,2,4,6$, and $8 \mathrm{~min}$, and width of the wound scar, using the statistical program SPSS 13.0. The Altman's nomogram for sample size calculations was used to determine the sample size. Results were expressed as mean \pm standard error from the mean (SEM). P $<0.05$ was considered significant.

\section{RESULTS}

\section{Tensile strength, elongation endurance before break- age, and elasticity coefficient}

Results showed that polyurethane suture threads had significantly better tensile strength, elongation endurance before breakage, and elasticity coefficient, as compared to polypropylene (Table 2). The same trend was observed when comparison was performed with polyamide. Similarly, polypropylene suture threads had significantly better tensile strength, and elasticity coefficient, as compared to the polyamide suture threads.

Table 2. Comparison of mean tensile strength, elongation, and elasticity coefficient of suture threads on 75 samples of the three different suture materials knot polypropylene, polyamide, and polyurethane. $\mathrm{N}=$ Newton, $\mathrm{n}=$ total number of samples, $\mathrm{SEM}=$ standard error from the mean. The tensile strength is the maximum strength that the suture thread can sustain against force before it breaks. Elongation is the maximum length that the suture thread can reach in association with the tensile strength. The elasticity coefficient reflects the degree of elasticity of the suture thread while reacting to a traction force. ${ }^{*} \mathrm{P}<$ 0.05 is considered significant.

\begin{tabular}{|l|lll|}
\hline & $\begin{array}{l}\text { Tensile } \\
\text { strength } \\
\text { (Mean } \pm \\
\text { SEM) }(\mathbf{N})\end{array}$ & $\begin{array}{l}\text { Elongation } \\
\text { (Mean } \pm \\
\text { SEM) }(\mathbf{c m})\end{array}$ & $\begin{array}{l}\text { Elasticity } \\
\text { coefficient } \\
\text { (Mean } \pm \\
\text { SEM) }\end{array}$ \\
\hline Polyurethane (n- 25) & $16.4 \pm 0.78$ & $2.48 \pm 0.13$ & $7.12 \pm 0.01$ \\
\hline $\begin{array}{l}\text { Polypropylene (n- 25) } \\
\text { Polyamide (n- 25) }\end{array}$ & $13.7 \pm 0.64$ & $1.94 \pm 0.09$ & $1.42 \pm 0.05$ \\
\hline $\begin{array}{l}\text { Polyurethane versus } \\
\text { Polypropylene }\end{array}$ & $\begin{array}{l}11.1 \pm 0.27 \\
\text { Palue }\end{array}$ & $1.84 \pm 0.10$ & $1.13 \pm 0.03$ \\
\hline $\begin{array}{l}\text { Polypropylene versus } \\
\text { Polyamide }\end{array}$ & $=0.015^{*}$ & $=0.47$ & $<0.001^{*}$ \\
$\begin{array}{l}\text { Polyurethane versus } \\
\text { Polyamide }\end{array}$ & $=0.001^{*}$ & $=0.003^{*}$ & $<0.0001^{*}$ \\
\hline
\end{tabular}




\section{Permeability}

The permeability of the three different suture threads examined in this study was tested using bromoethylene blue stain. The results showed that the polyurethane suture threads were the most impermeable, followed by polypropylene, and polyamide (Table 3, and Figure 1). The significant difference in the permeability of the suture threads was observed at 0,2 , 4,6 , and 8 minute-intervals. The stain did not dry at any of the above time intervals.

Table 3. Gradual absorption of stain through the three different suture threads examined, as determined by measuring the surface area of the stain at different time intervals $(\mathrm{T} 0=0$ minute, $\mathrm{T} 2=2$ minutes, $\mathrm{T} 4=4$ minutes, $\mathrm{T} 6=6$ minutes, and $\mathrm{T} 8=8$ minutes). There was significant difference in the permeability of the stain through the three different suture threads, starting from 2 minutes after the stain was added. $n=$ total number of samples. $\mathrm{SEM}=$ standard error from the mean. $* \mathrm{P}<0.05$ is considered significant.

\begin{tabular}{|c|c|c|c|c|c|c|}
\hline & \multicolumn{5}{|c|}{ Stained Surface Area (Mean \pm SEM mm²) } \\
\hline & & T0 & T2 & T4 & T6 & T8 \\
\hline \multicolumn{2}{|c|}{ Polyurethane (n- 25) } & $\begin{array}{l}360 \pm \\
1.4\end{array}$ & $330 \pm 0.6$ & $\begin{array}{l}270 \pm \\
3.8\end{array}$ & $144 \pm 0.7$ & $28 \pm 1.1$ \\
\hline \multicolumn{2}{|c|}{ Polypropylene (n- 25) } & $\begin{array}{l}360 \pm \\
2.1\end{array}$ & $300 \pm 0.2$ & $\begin{array}{l}243 \pm \\
4.1\end{array}$ & $72 \pm 0.9$ & $9 \pm 2.4$ \\
\hline \multicolumn{2}{|c|}{ Polyamide (n- 25) } & $\begin{array}{l}360 \pm \\
3.0\end{array}$ & $252 \pm 1.7$ & 0 & 0 & 0 \\
\hline \multirow[t]{3}{*}{$\begin{array}{l}P \\
\text { value }\end{array}$} & $\begin{array}{l}\text { Polyurethane } \\
\text { versus Polypro- } \\
\text { pylene }\end{array}$ & $=1$ & $<0.0001^{*}$ & $\begin{array}{l}< \\
0.0001^{*}\end{array}$ & $\begin{array}{l}< \\
0.0001^{*}\end{array}$ & $\begin{array}{l}< \\
0.0001^{*}\end{array}$ \\
\hline & $\begin{array}{l}\text { Polypropylene } \\
\text { versus } \\
\text { Polyamide }\end{array}$ & $=1$ & $<0.0001^{*}$ & $\begin{array}{l}<.0001^{*}\end{array}$ & $\begin{array}{l}<.0001^{*} \\
\end{array}$ & $\begin{array}{l}< \\
0.0001^{*}\end{array}$ \\
\hline & $\begin{array}{l}\text { Polyurethane } \\
\text { versus } \\
\text { Polyamide }\end{array}$ & $=1$ & $<0.0001^{*}$ & $\begin{array}{l}< \\
0.0001^{*}\end{array}$ & $\begin{array}{l}< \\
0.0001^{*}\end{array}$ & $\begin{array}{l}< \\
0.0001^{*}\end{array}$ \\
\hline
\end{tabular}
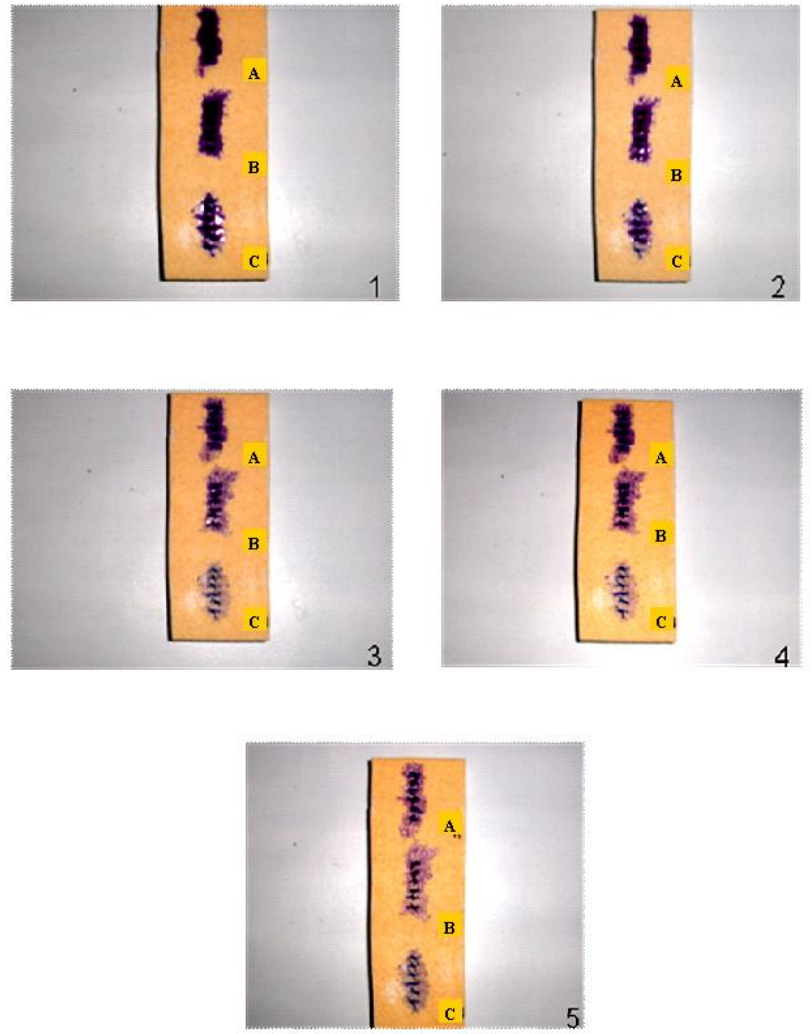

Figure 1: Progressive absorption of the stain through the three different suture threads (polyurethane [A], polypropylene [B], and polyamide $[\mathrm{C}]$ ), as examined at different time intervals following the addition of the stain $(1=$ at 0 minute, $2=$ at 2 minutes, $3=$ at 4 minutes, $4=$ at 6 minutes, and $5=$ at 8 minutes). It took significantly $(\mathrm{P}<0.0001)$ longer time for the stain to permeate the polyurethane suture threads, followed by polypropylene and polyamide.

\section{Scar formation}

As far as suture-type associated scar formation, the results showed that the least amount of scar was present when the polyurethane suture was used, as compared to polypropylene and polyamide (Table 4, and Figure 2). This was consistent in all the four different operations in which the above three different suture types were compared. Such operations pertained to laparocele, hernia, lipoma, and scar revision. No significant difference was observed between polypropylene and polyamide in laparocele, hernia, lipoma, and scar revision.

Table 4. Linear skin sutures performed during surgeries on laparocele, hernia, lipoma, and scar revision. Every wound was sutured with three different suture threads (polyurethane, polypropylene, and polyamide), which were placed randomly on the wound line. The size of the scar associated with the usage of the polyurethane suture threads was significantly $(\mathrm{P}<0.0001)$ less than that associated with the usage of the polypropylene and polyamide suture threads. $n=$ total number of cases. $\mathrm{SEM}=\mathrm{standard}$ error from the mean. $* \mathrm{P}<0.05$ is considered significant.

\begin{tabular}{|c|c|c|c|c|c|c|c|c|c|}
\hline & \multicolumn{5}{|c|}{$\begin{array}{l}\text { Length of the wound line } \\
\text { (Mean } \pm \text { SEM) (mm) }\end{array}$} & \multicolumn{4}{|c|}{$\begin{array}{l}\text { Width of the scar } \\
\text { (Mean } \pm \text { SEM) }(\mathrm{mm})\end{array}$} \\
\hline & $\begin{array}{l}\text { Laparocele } \\
(\mathrm{n}=10)\end{array}$ & $\begin{array}{l}\text { Hernia } \\
(n=10)\end{array}$ & $\begin{array}{l}\text { Lipoma } \\
(\mathrm{n}=10)\end{array}$ & \multicolumn{2}{|c|}{$\begin{array}{l}\text { Scar revision } \\
(\mathrm{n}=10)\end{array}$} & $\begin{array}{l}\text { Laparocele } \\
(\mathrm{n}=10)\end{array}$ & $\begin{array}{l}\text { Hernia } \\
(\mathrm{n}=10)\end{array}$ & $\begin{array}{l}\text { Lipoma } \\
(n=10)\end{array}$ & $\begin{array}{l}\text { Scar Revision } \\
(n=10)\end{array}$ \\
\hline Polyurethane & $300 \pm 5$ & $150 \pm 0.7$ & $60 \pm 0.5$ & \multicolumn{2}{|c|}{$115 \pm 1.5$} & $0.23 \pm 0.01$ & $0.15 \pm 0.02$ & $0.2 \pm 0.01$ & $0.25 \pm 0.03$ \\
\hline Polypropylene & $300 \pm 4$ & $150 \pm 0.8$ & $60 \pm 0.9$ & \multicolumn{2}{|c|}{$115 \pm 1$} & $2.33 \pm 0.4$ & $2.55 \pm 0.3$ & $2.43 \pm 0.06$ & $2.48 \pm 0.06$ \\
\hline Polyamide & $300 \pm 4$ & $150 \pm 1$ & $60 \pm 1$ & \multicolumn{2}{|c|}{$115 \pm 0.9$} & $2.35 \pm 0.2$ & $2.6 \pm 0.1$ & $2.47 \pm 0.09$ & $2.5 \pm 0.08$ \\
\hline & & & & \multirow{3}{*}{$\begin{array}{l}P \\
\text { value }\end{array}$} & $\begin{array}{l}\text { Polyurethane versus } \\
\text { Polypropylene }\end{array}$ & $<0.0001^{*}$ & $<0.0001^{*}$ & $<0.0001^{*}$ & $<0.0001^{*}$ \\
\hline & & & & & $\begin{array}{l}\text { Polypropylene ver- } \\
\text { sus Polyamide }\end{array}$ & $=0.96$ & $=0.88$ & $=0.72$ & $=0.84$ \\
\hline & & & & & $\begin{array}{l}\text { Polyurethane versus } \\
\text { Polyamide }\end{array}$ & $<0.0001^{*}$ & $<0.0001^{*}$ & $<0.0001^{*}$ & $<0.0001^{*}$ \\
\hline
\end{tabular}



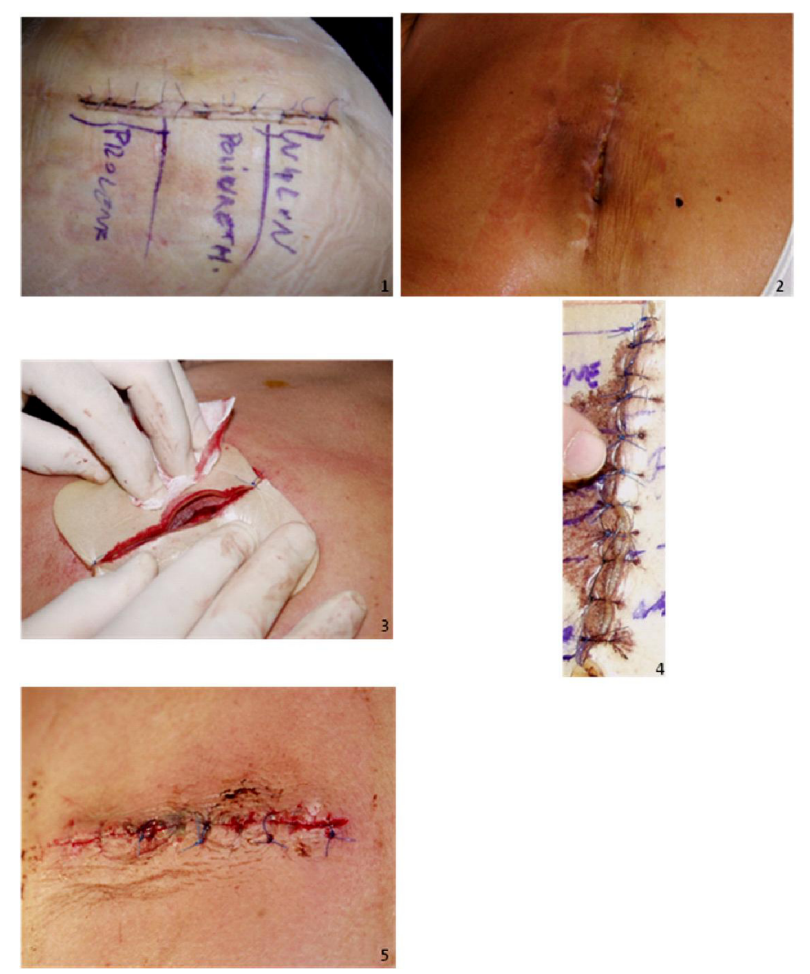

Figure 2: Sealing properties of three different suture threads (polyurethane, polypropylene, and polyamide) examined in this study. The first photo shows a skin suture applied following a right subcostal laparocele surgery. Note that the scar in the middle part of the suture line where polyurethane was used is very thin, as compared to wider scars in the lateral segments of the suture line where polyamide (left) and polypropylene (right) were used. The second photo shows a suture line following lipomectomy. Note that the lateral segments of the suture line, which were sutured using polyurethane, do not show any abnormalities, while the central segment, which was sutured using polypropylene and polyamide, shows unfitting margins, bigger scar, and exposure of subcutaneous tissue to infection. The last three photos are derived from the experimental protocol performed on hydrocolloids. Note that only polyurethane, which was used in the middle part of the suture line, was capable of providing a proper sealing of the wound.

\section{DISCUSSION}

Suture threads are still the most common means of wound closure, because they are readily available, easy to use, and efficient and because suture material provides the mechanical support necessary to sustain closure [14]. A wide variety of suture materials is available, and the surgeon can choose from a list of suture threads with a range of attributes to find the one best suited to the particular needs of the wound in question. When choosing an appropriate suture for wound closure and healing, considerations include the strength of suture, the holding power of the tissue, absorbability, risk of infection, and the inflammatory reaction associated with the suture material.

This study aimed at designing, in the lab first, and in the operative theatre later, an experimental protocol which would help surgeons better identify the optimal suture thread to be used in a way that would help maintaining the wound-margin coalescence during the first 24-72 hrs following operation, thus complying with the remodeling of the wound volume resulting from the clearance of edema in the injured tissues [15-19]. The saline-swollen artificial skin model, and the stain dropped over the suture using a standardized procedure, allowed the assessment of the water-proof property across the sutured line. The clinical pilot study using epidermal hydrocolloid thin layer coating was found to be very effective in detecting the proper tension of each knot. This is based on the significant $\mathrm{P}$ values consistently obtained for polyurethane in relation to all the outcomes measured (Tensile strength, elongation endurance before breakage, and elasticity coefficient; Permeability; Scar formation).

Using this study protocol, the results showed that polyurethane, followed by polypropylene and polyamide, seems to be the first choice to suture a swollen surgical wound, where the swelling is either due to using local anesthetic agents, or due to surgical trauma (like in traumatic wounds, venous lower legs surgery, perianal surface, etc.) $[11,20]$. The polyurethane thread is not stiff to be handled, is easily knotted, and holds very well the knot with excellent elastic compliance along the suture line. Moreover, being quite biocompatible, and thus stimulating a minor foreign body reaction, polyurethane should probably be given a special preference, especially when dealing with high-risk infection conditions such as following head and neck resection [21].

\section{CONFLICT OF INTEREST}

The authors have declared that no conflict of interest exists.

\section{REFERENCES}

1. Thiede A. Suture materials in surgery: Significances of basic substance and construction of surgical suture material for utilization in vivo. Fortschr Med. 1978; 96: 883-886.

2. Tomita N, Tamai S, Shimaya M, et al. A study on elongation and knot slacking of various suture threads. Biomed Mater Eng. 1992; 2: 71-77.

3. Bennett RG. Selection of wound closure materials. J Am Acad Dermatol. 1988; 18: 619-637.

4. Bonandrini L, Rosato S. Suture \& Ferri Chirurgici. Foligno, Italy: Il Salvalibro Snc Publisher; 1989.

5. Bloom BS, Goldberg DJ. Suture material in cosmetic cutaneous surgery. J Cosmet Laser Ther. 2007; 9: 41-45.

6. Charbit Y, Hitzig C, Bolla M, et al. Comparative study of physical properties of three suture materials: silk, e-PTFE (Gore-Tex), 
and PLA/PGA (Vicryl). Biomed Instrum Technol. 1999; 33: 71-75.

7. Irvin TT. Simple skin closure. Br J Hosp Med. 1985; 33: 325-330.

8. Meyer RD, Antonini CJ. A review of suture materials, Part II. Compendium. 1989; 10: 360-368.

9. Menaker GM. Wound closure materials in the new millennium. Curr Probl Dermatol. 2001; 20: 90-94.

10. Swanson NA, Tromovitch TA. Suture materials, 1980s: properties, uses, and abuses. Int J Dermatol. 1982; 21: 373-378.

11. Langton JA and Gale TCE. Day-case anaesthesia. In: Aitkenhead AR, Smith G, and Rowbotham DJ, ed. Textbook of Anaesthesia, $5^{\text {th }}$ ed. Philadelphia: Elsevier Ltd.; 2006: 533-539.

12. Gogolewski S, Pennings AJ. An artificial skin based on biodegradable polyurethane for full-thickness skin wound covering. Die Makromolekulare Chemie. 1983; 4: 675-680.

13. Brugal G, Garbay C, Giroud F, et al. A double scanning microphotometer for image analysis: hardware, software and biomedical applications. J Histochem Cytochem. 1979; 27: 144-152.

14. Spotnitz WD, Falstrom JK, Rodeheaver GT. The role of suture threads and fibrin sealant in wound healing. Surg Clin North Am.1997; 77: 651-669.

15. Tomita N, Tamai S, Morihara T, et al. Handling characteristics of braided suture materials for tight tying. J Appl Biomater. 1993; 4: 61-65.

16. Tomihata K, Suzuki M, Tomita N. Handling characteristics of poly (L-lactide-co-epsilon-caprolactone) monofilament suture. Biomed Mater Eng. 2005; 15: 381-391.

17. Vasquez G, Mascoli F, Rubbini M, et al. Vascular microsuture threads with reabsorbable and nonresorbable suture threads. A comparative study. Minerva Cardioangiol. 1991; 39: 177-184.

18. Wainstein M, Anderson J, Elder JS. Comparison of suture materials on wound healing in a rabbit pyeloplasty model. Urology. 1997; 49: 261-264.

19. Zerini M. Manuale delle suture e dei prodotti speciali. Modena, Italy: Ethicon Publisher; 2002.

20. Dellinger EP. Nosocomial infection. In: Souba WW, Mitchell P, Fink MD, Gregory J, Jurkovich MD, Larry P, Kaiser MD, Pearce WH, Pemberton JH, Soper NJ, eds. ACS Surgery, Principles \& Practice, 6th ed. New York: WebMed Professional Publishing. 2006: 1672-1689.

21. Barton RP, Moir AA. The prevention of wound infection after head and neck resections: A pilot study using gentamicin impregnated beads. Ann R Coll Surg Engl. 1984; 66: 98-100. 